\title{
A KÖTŐDÉS KULTURÁLIS KÜLÖNBSÉGEI ${ }^{1}$
}

\author{
FÜLÖP MÁRTA ${ }^{1,2}$ - SZABÓ ZSÓFIA ÉVA ${ }^{1}$ \\ ${ }^{1}$ MTA TTK Kognitív Idegtudományi és Pszichológiai Intézet \\ ${ }^{2}$ ELTE PPK Pszichológiai Intézet \\ E-mail:fulop.marta@ttk.mta.hu
}

Jelen tanulmány a kötôdéselméletet a kulturális összehasonlító vizsgálatok tükrében mutatja be. A kötôdés jelenségét univerzálisnak fogadja el, de a klasszikus elmélet által leírt legföbb fejlödési kritériumokat és a különbözö kötôdési mintázatok megnyilvánulásait kulturálisan meghatározottnak tekinti. Áttekintést nyújt azon vizsgálatokról, amelyek az elmúlt mintegy hat évtizedben a kötôdés kultúrközi különbségeinek témakörében születtek.

Elsôként tárgyalja az úgynevezett étikus vizsgálatokat, amelyek a kulturális különbségeket elsôsorban a különbözó kötôdési mintázatok elōfordulási gyakoriságában ragadják meg, majd sorra veszi az émikus megközelítéseket, amelyek a kötôdéselmélet számos alaptételét kérdôjelezik meg, így például az anya-gyerek kapcsolat monotropizációját, illetve etnocentrikusnak tekintik az anyai érzékenység megnyilvánulási kritériumait. A tanulmány azt a nézetet képviseli, hogy a kötôdési folyamatok a gyermeket körülvevố biológiai és társadalmi környezethez történô legjobb alkalmazkodást szolgálják, és ha a társadalmi-kulturális közeg az euro-amerikaitól eltérô, akkor a kötödés folyamatai is eltéröek lesznek.

Kulcsszavak: kötôdés, kulturális különbségek, anya-gyerek kapcsolat

A kötôdéselmélet a 20. század pszichológiai elméletei közül az egyik legsikeresebb, amelyre számos családi intervenciós program is épül szerte a világon (van IJzendoorn és Sagi-Schwartz, 2008; Rothbaum, Weisz, Pott, Miyake és Morelli, 2000; Keller, 2013). Ugyanakkor a kötődés és kultúra kapcsolata a kötôdéskutatás egyik viszonylag késôn

${ }^{1}$ A tanulmány megírása során a szerzôk az OTKA K111789 számú (vezetô kutató: dr. Fülöp Márta), a „A mentálhigiénésen és szomatikusan egészséges versengés egyéni, szituatív és szociokulturális determinánsai” címú pályázat támogatásában részesültek. 
figyelmet kapott ága. Ennek egyik oka az lehet, hogy mivel a kötôdési folyamatokat primátáknál és más fajoknál is megfigyelték, és azoknak biológiai, evolúciós jelentôséget tulajdonítottak, ezért a kutatók elsôsorban annak univerzális voltára helyezték a hangsúlyt. Az emberi csecsemô túlélését segítô kötôdés kultúrától függetlenül mindenütt szükséges folyamat (Bowlby, 1969), ami persze nem jelenti azt, hogy ne lehetnének kultúraspecifikus vonásai, pontosan az adott környezeti feltételekhez való adaptív alkalmazkodás érdekében (Hinde és Stevenson-Hinde, 1990). Ez a kérdés az utóbbi két évtizedben számos kutatót inspirált különbözô módszerú kutatómunkára. A kötôdés kulturális aspektusainak kutatói között a mai napig élénk vita folyik arról, hogy valójában milyen és mekkora szerepe van a kultúrának egy alapvetôen biológiailag meghatározott pszichés jelenség alakulásában.

Már John Bowlby munkásságágában felmerültek a kultúra hatásaival kapcsolatos kérdések. Bowlbyt 1950-ben felkérte a WHO, hogy készítsen egy tanulmányt a háború utáni európai hontalan és árva gyermekek mentális egészségérôl. Kutatásában hat európai országból és az USA-ból gyújtött adatokat. Bowlby (1951) legfôbb következtetése az volt, hogy ahhoz, hogy egy gyermek mentálisan egészségesen nôjön fel, meleg, intim és folyamatos kapcsolatra van szüksége az anyjával (vagy egy állandó anyahelyettessel), valamint arra, hogy ez a kapcsolat mindkettejük számára kielégító és örömteli kell hogy legyen. Bár ezt a következtetést univerzálisan igaznak tekintette, erôsen hangsúlyozta azt is, hogy nagyon fontos faktor az anya-gyermek kapcsolat alakulása szempontjából a szocioökonómiai környezet és az anya szociális hálója. Bowlby késôbb számos publikációjában (1973, 1980; Bretherton, 1992) utalt arra, hogy eredményeit a nyugati kultúrában végzett kutatások során tárta fel, továbbá hogy más kultúrában elképzelhetô, hogy a nyugatitól eltérô hagyományokból kiindulva eltérô eredmények születtek volna.

Mary Ainsworth 1950-ben ismerkedett meg Bowlby munkásságával, és együtt is dolgoztak 1953-ig, amikor Ainsworth a férjét követve Ugandába költözött. Így voltaképpen az anya és gyermek között kialakuló kapcsolatot elôbb tanulmányozta egy számára idegen kultúrában, mint a sajátjában. A háromféle kötôdési típust, a biztonságosat, a szorongó-elkerülôt és a szorongó-ambivalenset ${ }^{2}$ valójában ugandai anya-gyerek párok megfigyelésére alapozta. Baltimore-ban 1963-ban egy nyugati középosztálybeli kultúrában folytatta az ugandai kutatásokat, kifejezetten azzal a céllal, hogy feltárja, vajon ugyanazokat a kapcsolódási mintázatokat tudja-e azonosítani, és ezek a mintázatok univerzálisak-e. Ugandában két éven át a terepen való megfigyelés módszerét választotta, amely alkalmas a kontextus kulturális jellegzetességeinek feltárására. Eleinte az USA-ban is az otthoni megfigyelés módszerét alkalmazta a gondozó-gyermek párok vizsgálatára, amelynek eredményei nem egyeztek meg az Ugandában találtakkal. Az amerikai csecsemốk sokkal jobban hozzá voltak szokva ahhoz, hogy az anya

\footnotetext{
${ }^{2}$ A három klasszikus típus elnevezése a szakirodalomban igen változatos. A biztonságos (secure, B típus) kötôdést konzekvensen ilyen formában használják mindenütt, míg az elkerülô (avoidant, A típus) és a szorongó-ambivalens (insecure resistant, C típus) fordítása színes. Tóth és Gervai (2005) a biztonságos, bizonytalan-elkerülô/elkerülô és bizonytalan-rezisztens/rezisztens kifejezéseket használják, míg Hámori és munkatársai (2016) a biztonságos, szorongó-elkerülő/elkerülő és szorongó-ambivalens elnevezéseket preferálják. Mi ehelyütt nem ragaszkodunk egyik nomenklatúrához sem, minthogy egy jelenséget jelölnek, hanem azokat váltogatva használjuk.
} 
elmegy és visszajön, miközben ók mással vannak, jobban viselték, ha az anya elment, és kevesebbet sírtak, vagyis az „elszakadásra” otthoni helyzetben kevésbé reagáltak (Keller, 2013). Az Idegen Helyzet paradigmát Ainsworth (1969) valójában azért fejlesztette ki, mert az amerikai csecsemốk számára nehezített helyzetet kívánt teremteni, hogy az otthon megfigyelt ugandai csecsemókhöz hasonló reakciókat válthasson ki belölük. Ezt írta:

„Ki kell használnunk a kultúraközi kutatások elônyeit, és a „lehetôség adta kísérleteket" a saját kultúránkon belül annak érdekében, hogy megvizsgáljuk, a különbözô csecsemőgondozási minták hogyan hatnak a csecsemôk kötôdésére a gondozásukban részt vevốk iránt"(Ainsworth, 1978/2014, 308).

Bowlby és Ainsworth a fenti szempontok említésén túl nem szenteltek figyelmet saját munkásságukban a kötôdés kulturális vonatkozásainak, és mások munkásságában sem jelent meg ez a szempont évtizedeken keresztül. A kötôdés evolúciós alapjainak és eredetének egyértelmú elfogadása egyet jelentett azzal, hogy a jelenséget tökéletesen univerzálisnak tekintették (Keller, 2013). Egészen az 1990-es évek végéig összesen 14 olyan kutatást tudtak összeszedni a kutatók, amelyek a kötôdést kultúraközi aspektusból vizsgálták (van IJzendoorn és Sagi, 1999). Ezek a korai kutatások úgynevezett étikus kutatások voltak. Az étikus megközelítés a pszichés jelenségeket az emberiségre nézve univerzálisan azonosnak tekinti, és a különbözô kultúrákban elvégzett kutatásokat elsôsorban az motiválja, hogy ezt be is bizonyítsák. Ezeknek a kutatásoknak nem célja a kulturális hatások mélyebb megértése. Az azonosságok és nem a különbözôségek állnak a figyelem középpontjában. Ennek megfelelôen a kutatók egy-egy, a saját kultúrájukban kidolgozott módszert (kísérleti helyzet, kérdőív) módosítás nélkül, azonos - sztenderd - módon alkalmaznak más kultúrákban (Nguyen Luu, 2003). Ha a módszerrel az adott elméleti kereten belül értelmezhetô eredmények születnek, akkor az a jelenség univerzális voltát bizonyítja. Ezzel szemben, ha egyes vizsgált összetevôk aránya eltér egymástól, akkor ezt a mennyiségi eltérést a kultúra hatásának tulajdonítják. Paradox módon, miközben Mary Ainsworth éppen az eltérô kulturális közeg miatt dolgozta ki a korábban alkalmazott megfigyelés módszere helyett az Idegen Helyzetet, az a késóbbiekben etalonná vált. Magát az így kialakított vizsgálati helyzetet minden kulturális szempont tekintetbevétele nélkül széleskörúen alkalmazták a legkülönbözóbb, az amerikai középosztályétól erôsen eltérô környezetekben is, mint például a gusziknál Kenyában (Kermoian és Leiderman, 1986) vagy a hauszáknál Nigériában (Marvin, Van Devender, Iwanaga, LeVine és LeVine, 1977). Ainsworth a pszichés jelenség összehasonlíthatóságára törekedett, amikor Baltimore-ban bevezette a helyzetet, ami a gyerekból stresszt tud kiváltani. Vagyis az érzelmi reakciónak és nem az azt kiváltó helyzetnek kellett azonosnak lennie. A késóbbiekben mégis a helyzet vált a kutatás vezérfonalává, nem a pszichés jelenség. Egy-egy kutatásban abban az értelemben mégis kulturálisan szenzitívek voltak a kutatók, hogy az eltérô kultúrájú csecsemó magatartásában más-más viselkedéses elemet tekintettek a biztonságos kötôdés kifejezésének, mint az eredeti kísérletben. Így például az amerikai csecsemôk ölelésének a guszi csecsemôk kézrázása felelt meg (Kermoian és Leiderman, 1986).

A 2000-es években indultak el az úgynevezett émikus megközelítés szükségességét hangsúlyozó kötôdéskutatások, amelyek alapálláspontja az volt, hogy a pszichés jelenségek minôségileg térnek el egymástól a különbözô kultúrákban. Egy-egy helyzet adott 
kultúrában elnyert specifikus jelentésének feltárása nélkül, pusztán mennyiségi összehasonlítással téves értelmezésekre juthatunk. Ennek megfelelően olyan vizsgálati módszereket kell alkalmazni, amelyek képesek feltárni a kulturális konstrukciókat, és azok ismeretében kell kidolgozni újabb, adekvát kutatási módszereket. Eszerint lehet, hogy egy módszer, amely alkalmas egy adott kultúrában egy jelenség feltárására, tökéletesen alkalmatlan lehet és félrevezetô eredményekre vezethet egy másikban (Rothbaum és Morelli, 2005; Rothbaum, Kakinuma, Nagaoka és Azuma, 2007; Keller, 2013, 2016).

\section{A KÖTŐDÉS UNIVERZÁLIS JELENSÉGÉBŌL KIINDULÓ KULTÚRAKÖZI KÖTŐDÉSKUTATÁSOK}

Az úgynevezett étikus kulturális összehasonlító kutatások középpontjában az univerzálisnak tekintett viselkedéskategóriák állnak. Széleskörúen alkalmazott, jól validált eszközöket használnak, és többnyire kidolgozott elméleti háttérrel rendelkeznek. Céljuk az, hogy a kultúraspecifikus változatokon belül a kultúrától függetlennek mutatkozót tudják azonosítani (Nguyen Luu, 2003). Az elsô étikus kötődésvizsgálatok Ainsworth Idegen Helyzet paradigmájának ismétlései voltak, vagyis az általa kidolgozott sztenderd kísérleti helyzetet „utaztatták” különböző országokba. Elsôsorban nem azzal a céllal, hogy a jelenség kulturális meghatározottságát tárják fel, hanem épp ellenkezôleg, azt igyekeztek bizonyítani, hogy a kötôdési mintázatok nagyon különbözô helyeken is azonosak, tehát univerzálisak. Baltimore után az elsố ilyen kutatást a Német Szövetségi Köztársaságban, Bielefeldben végezték el Grossmann és munkatársai (Grossmann, Grossmann, Huber és Wartner, 1981; Grossmann, Grossman, Spangler, Suess és Unzner, 1985). Pontosan követték az eredeti kísérleti elrendezést. Bár sikerült mindhárom eredetileg feltárt kötôdési mintázatot azonosítaniuk, de a mintázatok közötti megoszlás eltért az amerikai eredményektôl. A kutatók számára váratlan módon a német csecsemốk között jóval alacsonyabb volt a biztonságosan kötôdôk aránya, és jóval magasabb a szorongóké, mint az USA-ban (lásd 1. táblázat). Míg a szorongó-ambivalensek száma megegyezett az amerikai mintán találtakkal, a szorongó-elkerülók aránya szignifikánsan magasabb volt az amerikai arányhoz képest. Mivel a kötôdési szakirodalom csak a biztonságos kötôdést kapcsolta össze az egészséges mentális fejlôdéssel (Bowlby, 1979), Grossmanéknak azon kellett gondolkodniuk, hogy vajon a német gyerekek pszichésen betegebb felnôttek lesznek-e, mint az amerikaiak. Erre vonatkozóan semmilyen alátámasztó adat nem volt, így az eredményeket a kulturális normáknak való megfelelésként értelmezték. Vagyis annak, hogy a német kultúrában nagyobb a távolságtartás, kevesebb a testkontaktus az anya és a gyermek között, a gyermekkel való folyamatos kontaktust kényeztetésnek tekintik. Ugyanakkor az eredeti klasszifikáció a szoros testkontaktust tekinti a biztonságos kötôdés egyik jelének. Mivel ezt a német anyák és gyerekek kevésbé keresték, ezért a gyerekeket a szorongó-elkerülố kötôdôk közé sorolták, és a német anyákat a testkontaktus alacsonyabb aránya miatt kevésbé érzékenynek tekintették, és a talált eredményt fejlôdési anomáliaként kezelték. Grossmannék ezért felvetették, hogy lehet, hogy az eredménynek semmi köze az anyák érzékenységéhez vagy elutasító magatartásához, hanem a kulturális környezet elvárása más, és ennek megfelelôen az anyák is másra szocializálják gyermekeiket. Az 
észak-német anyák nem testkontaktussal igyekeztek megnyugtatni a csecsemôket, hanem más, disztálisabb módokon, ezért lehet, hogy a csecsemók egy része is hasonló módon (azaz disztálisan) keres megnyugtatást. Öket a rendszer a „patológiás” csoportba sorolja (Atkinson, 1997). Grossman és munkatársai (1985) komoly kritikai megállapítást tettek az eredményeik átgondolása után. Eszerint, ha az anyák magatartását egy, a kulturális sajátosságokra nem érzékeny sztenderd értékelô rendszer alapján értelmezik és kategorizálják, azaz a szélesebb kötődés koncepciót egy szúk és merev operacionalizációba kényszerítik bele, akkor felmerül az a lehetôség, hogy teljesen téves következtetésekre juthatnak.

Sagi és munkatársai egy különleges gyermeknevelési közegben tesztelték az Idegen Helyzet érvényességét: az izraeli kibucokban (Sagi, Lamb, Lewkowitz, Shoham, Dvir és Estes, 1985). A kibucban született gyermekek 3 hónapos korukig élnek az édesanyjuk közvetlen közelében, majd úgynevezett gyerekházakba költöznek. A napjaik nagy részét az édesanyjukkal, illetve egy kijelölt nevelóvel (metapelet) töltik, de éjszakára visszatérnek a gyermekházakba, és voltaképpen ott nônek fel. Egyéves koruktól kezdve naponta csak néhány órát tölthetnek a szülôkkel, a napjuk nagy részét a metapelettel és a kortársakkal töltik. A hagyományos családban nevelkedô izraeli csecsemôkhöz képest kisebb arányban találtak biztonságosan kötôdô csecsemôket a kibucban nevelkedôk között (lásd 1. táblázat). Minden izraeli vizsgálatban (akár városi, akár kibucban vett mintáról volt szó) nagyobb arányban találtak szorongó-ambivalens kötôdésû csecsemôket, mint elkerülôket. A lefolytatott Idegen Helyzetek mintegy harmadát meg kellett szakítani vagy módosítani kellett, mert a csecsemók stresszreakciója nem oldódott fel. A szerzók ezt azzal magyarázták, hogy az izraeli társadalom folyamatos fenyegetettségben él, ami megnöveli a szülôk szorongásszintjét, és túlóvó magatartást eredményez. Tulajdonképpen azt állították, hogy a szorongó-ambivalens kötôdés nem „fejlődési anomália”, hanem valójában adaptív válasz lehet egy környezeti tényezóre.

Az Idegen Helyzet vizsgálatot Japánban, egy, az amerikaitól és az európaitól erôsen eltérô kultúrában két alkalommal is elvégezték: Tokióban és Szapporóban. A két vizsgálat különböző, egymásnak ellentmondó eredményeket mutatott. A Tokióban 32 anya-gyerek párral végzett vizsgálat alapján a kutatók a kötôdési mintázatok univerzalitására találtak bizonyítékot, ugyanis a baltimore-i vizsgálattal megegyezô arányban találták meg a háromféle kötôdési mintázatot (Durrett, Otaki és Richards, 1984, lásd 1. táblázat). A Szapporóban 60 anya-gyerek párral végzett vizsgálatban viszont Takahashi (1986) sajátságos képet mutatott ki a japán gondozó-gyermek diádok kötôdési mintázatával kapcsolatosan. A biztonságosan kötôdô mintázat ott is túlsúlyban volt, ellenben a bizonytalan kötôdés elkerülố mintázata nem volt kimutatható, és a szorongó-ambivalens kötôdés sokkal nagyobb arányban volt reprezentálva, mint más kultúrákban (lásd 1. táblázat). A szorongó-ambivalens kötôdésú gyermekek magas arányát a kutató számos mediáló faktorral magyarázta, melyek nagyrészt a nyugatihoz képest szorosabbnak mondható anya-gyermek kapcsolatra vezethetôk vissza (pl. drámaian erôsebb stresszreakció az anya és a gyermek részérôl is az Idegen Helyzetben). Az elkerülô magatartás hiányát pedig azzal, hogy a japán kultúra nem engedi az anyáknak az elutasító magatartást, így az elkerüló kötôdés a gyermeknél nem lehet normatív/ adaptív. A szerzô figyelmeztet azonban, hogy az eredeti klasszifikáció nehezen alkal- 
1.táblázat. Kötôdési típusok százalékos eloszlása különbözô országokban (van IJzendoorn és Sagi-Schwartz, 2008; Gervai és mtsai, 2005)

\begin{tabular}{lccc}
\hline & Biztonságos & $\begin{array}{c}\text { Bizonytalan-ambi- } \\
\text { valens }\end{array}$ & Elkerülő \\
\hline USA (21 vizsgálat alapján) & $67 \%$ & $12 \%$ & $21 \%$ \\
Bielefeld (Németország) & $33 \%$ & $12 \%$ & $45 \%$ \\
Izrael (kibuc, külön alvás) & $56 \%$ & $37 \%$ & $7 \%$ \\
Izrael (város) & $72 \%$ & $21 \%$ & $3 \%$ \\
Tokió (Japán) & $61 \%$ & $18 \%$ & $13 \%$ \\
Szapporó (Japán) & $68 \%$ & $32 \%$ & $0 \%$ \\
Magyarország & $52 \%$ & $11 \%$ & $16 \%$ \\
\hline
\end{tabular}

(Egy részletesebb és több kultúrára kiterjedô táblázatot lásd Hámori, 2015, 77.)

mazható a japán mintán, ugyanis a legtöbb gyermek valamilyen kevert kötôdési mintázatot mutatott. Ez nyilvánvalóan megkérdőjelezi a klasszifikáció érvényességét az adott kultúrára.

A fenti kutatások óta a világ majdnem összes országában lefolytatták az Idegen Helyzet kísérletet. Magyarországon elōször 2005-ben Gervai Judit és munkatársai (Tóth és Gervai, 2005; Tóth, 2011) végeztek ilyen vizsgálatot, és a következó eloszlást találták: a csecsemốk 52\%-a biztonságosan kötôdô, 16\%-a bizonytalan-elkerülő, 11\%-a pedig bizonytalan-ambivalens volt (lásd 1. táblázat). Ebben a vizsgálatban a gyerekek fennmaradó 21\%-a a dezorganizált kötôdési csoportba tartozott. Dezorganizált kötôdéssel kapcsolatos metaanalízisükben van IJzendoorn, Shuengel és Bakermans-Kranenburg (1999) kulturális eltérésekkel kapcsolatos elemzéseket is végeztek. Több életkori szakasz elemzése során azt találták, hogy a kutatásokba bevont amerikai középosztálybeli csecsemôk és idôsebb gyermekek 15\%-a jellemezhetô dezorganizált kötôdéssel. Ezzel szemben más nyugati kultúrákban ez az arány 17\%, a nem nyugati kultúrákban pedig $21 \%$ volt. Mindezek tükrében a magyar mintán kapott $21 \%$-os arány (Tóth és Gervai, 2005) a nem-nyugati kultúrákhoz hasonlít.

Heidi Keller (2013) az Idegen Helyzet validitásával kapcsolatban azt a kritikát vetette fel, hogy számos népnél, például a nyugat-afrikai bengeknél, vagy a Kamerunban élô Nso törzsnél az idegen személy megjelenése nem párosul semmilyen stresszreakcióval. Tehát ebben a kontextusban nincs értelme az Idegen Helyzetet használni, mert az nem váltja ki a gyermekben azt a stresszt, amellyel kapcsolatban az anyai megnyugtatást és a gyerek erre adott reakcióját kívánják mérni. A fentebb már érintett japán vizsgálatokban (Takahashi, 1986) ezzel szemben egy másik végletes reakció jelent meg. A japán gyermekek magukra hagyva olyan drámai stresszt éltek meg, hogy ezt a szakaszt a kutatóknak a gyermekek 90\%-ánál drasztikusan le kellett rövidíteni, 10\%-ánál pedig teljesen ki kellett hagyni. Az azonos vizsgálati helyzet tehát kultúránként nagyon különbözô jelentéssel és hatással bírhat.

A fenti probléma feloldására dolgozták ki a Q-rendezés módszerét (Attachment Q-sort, Waters és Deane, 1985), azaz éppen az olyan esetekre, amelyekben az Idegen Helyzet használata nem adekvát, szerencsés. Előnyei az Idegen Helyzettel szemben, hogy a megfigyelés otthoni környezetben zajik, így nagyobb az ökológiai validitása, 
korban szélesebb mintán, illetve egy csecsemônél több alkalommal is használható. Emellett nem a szeparációs stresszre épít, így olyan kultúrákban is használható, ahol a szeparáció ismeretlen fogalom. Ez utóbbi azért is hasznos, mert így lehetôséget ad az egy-egy kultúrára jellemzô prototipikus kötôdési viselkedés leírására (van IJzendoorn, Vereijken, Bakermans-Kranenburg és Riksen-Walraven, 2004). A módszer egy viselkedésleltárt tartalmaz, amely viselkedéseket 12 és 48 hónapos kor közötti gyerekeknél figyeltek meg otthoni környezetben. Az anyáknak meg kell ítélniük, hogy mennyire tartják igaznak ezeket a viselkedéseket a saját gyerekükre. Posada és munkatársai (1995) hét országban (pl. Kína, Japán, Németország, Izrael) folytatott vizsgálatukban azt találták, hogy az anyák nagyon hasonló leírást adtak az ideálisan kötôdô gyerekrôl, és ez a leírás a biztonságos kötôdés koncepciójához közelített. Keller (2013) ugyanakkor rámutatott arra, hogy minden országban magasan iskolázott, középosztálybeli társadalmi rétegbool kikerülő és hasonló nevelési értékrendszerú anyák vettek részt a vizsgálatokban. Ez felvetette annak a kérdését, hogy mennyiben képeznek a társadalmi rétegek közötti eltérések kulturális különbségeket, és mennyiben lehetséges az, hogy egy adott kultúrán belül a különbözô társadalmi rétegek között nagyobbak a különbségek, mint különbözô kultúrák azonos társadalmi rétegbôl származó egyedei között.

Van IJzendoorn és Sagi-Schwartz (2008) áttekintték az Idegen Helyzettel végzett addigi kultúraközi vizsgálatokat. Azt a következtetést vonták le, hogy a különbözó nyugati és nem-nyugati kultúrákban egyaránt kialakul egy kiemelt személlyel a kötôdés, és megjelennek annak különbözô típusai is. A biztonságos, az elkerülô és a bizonytalan-ambivalens kötődést megfigyelték afrikai, kínai, indonéziai és japán vizsgálatokban, és még a nagyon különleges izraeli kibucban is különbséget lehetett tenni a biztonságos és bizonytalan kötôdésû gyerekek között. Minden vizsgált csoportban a biztonságos kötôdés volt a leggyakrabban megtalálható. Ezek alapján amellett érvelnek, hogy a kötôdés evolúciósan megalapozott, univerzális és normatív jelenség, amelynek azonban lehetnek kulturálisan specifikus viselkedéses jegyei (összefoglalást lásd Hámori, 2015).

\section{Túl a csecsemókoron}

Az Idegen Helyzettel végzett elsô kultúraközi kutatások a csecsemôkori kötôdést vizsgálták. Pedig, mint arra Bowlby (1979) is felhívta a figyelmet: „a kötôdésviselkedés a bölcsôtôl a sírig jellemzi az emberi lényeket” (129). A késôbbi életkorokban végzett elenyészô számú vizsgálatra ugyancsak leginkább a kutatási módszerek „utaztatása” volt jellemzô, vagyis azokat módosítás nélkül használták a nyugatitól eltérô kultúrákban is. Ezek a kutatások rendre a módszer alkalmazhatóságával kapcsolatos fenntartásokkal végzôdtek.

Óvodáskorban az egyik lehetséges vizsgálómódszer, amellyel a kötôdést is értékelni lehet, a családrajz. Olyan projekciós eszköz, amely hozzásegíti a kutatót a gyermekben élő komplex fogalmi reprezentációk megismeréséhez. Gernhard és munkatársai (Gernhardt, Keller és Rübeling, 2016) például német és kameruni gyermekek családrajzait hasonlították össze. A hagyományos nyugati értékelőrendszerrel osztá- 
lyozva a rajzokat, szignifikánsan több bizonytalanul és szignifikánsan kevesebb biztonságosan kötôdô kameruni gyermeket találtak. A szerzôk azonban arra hívják fel a figyelmet, hogy értékelésükben azokra a grafikus jelekre támaszkodtak, amelyeket a nyugati kultúrában értelmeznek a bizonytalan kötôdés megnyilvánulásaiként (neutrális arcok, kicsiny méretek, kidolgozatlanság), és amelyek nem feltétlenül rendelkeznek azonos jelentéssel más kultúrákban. A rajzokat nem lehet az adott kultúrában megnyilvánuló szocializációs céloktól függetlenül értelmezni. Így például a kameruni gyerekeknél nem feltétlenül a bizonytalan kötôdés jele, hogy a családrajzon nincs rajta az anya figurája, miközben sok mindenki mást megjelenít a gyermek. Az sem a bizonytalan kötôdés jele, hogy az alakok kicsik és a szülő́k sem emelkednek ki a többi figura közül. A szerzôk ezért azt hangsúlyozzák, hogy olyan értelmezési, pontozási rendszert kell kialakítani, amely képes arra, hogy az adott kultúrán belül tudja értékelni a kötôdés milyenségét.

Sajnos kötôdéssel kapcsolatos serdülốkori kultúraközi vizsgálat nem ismert. Habár a serdülőkori kötôdés mérésére specifikus eszközöket is kifejlesztettek, mint például a Szülő-Kortárs Kötôdési Leltárt (Inventory of Parent and Peer Attachment [IPPA] Armsden és Greenberg, 1987), a serdülőkor kötôdési sajátosságainak kulturális variációit azonban mind ez idáig nem vizsgálta senki.

A felnôtt kötődés mérésére a legegyszerúbb megoldásnak az önbevalláson alapuló kérdőívek kifejlesztése mutatkozott. Wang és Mallinckrodt (2006) például a Közeli Kapcsolati Tapasztalatok Skálát (Experiences in Close Relationship Scale [ECRS], Brennan, Clark és Shaver, 1998) használva igyekeztek feltárni, milyen kötôdést tartanak ideálisnak fiatal amerikai és tajvani felnôttek. Vizsgálatuk elôtt viszonylag kevés felnốtteket összehasonlító tanulmány született, de ezek nagy része azt az eredményt kapta, hogy Kelet-Ázsiában hangsúlyosabb a bizonytalan-ambivalens kötôdés a fiatal felnôttek körében, mint Európában vagy Észak-Amerikában (Ditommaso, Brannen és Burgess, 2005). You és Malley-Morrison (2000) koreai és amerikai egyetemistákat összehasonlító kutatásukban a Kötôdési Stílus Kérdôívvel (Attachment Style Questionnaire [ASQ], Feeney, Noller és Hanrahan, 1994) az ázsiai fiatal felnôttek között több aggodalmaskodóan kötôdôt találtak. Baráti kapcsolataikban kevesebb volt az intimitás, mint az amerikai fiatalok esetében. Wangék eredményei is összhangban voltak ezekkel a korábbi eredményekkel. A tajvani fiatal felnôttek a bizonytalan szorongó kötődést nagyobb arányban tartották ideálisnak, mint az amerikaiak. A mérôeszközt itthon Hámori és munkatársai fordították, validálták és használták (Hámori, Dankháziné Hajtman, Urbán, Martos, Kézdy, Horváth-Szabó, 2016). A magyar mintán a különbözố kötôdési típusok következô arányát találták: biztonságosan kötôdött a minta 54\%-a, elkerülốn 14,3\%-a, szorongó ambivalensen pedig 31,7\%-a.

Schmitt és munkatársai (2004) 62 kulturális csoportban vették fel a Kapcsolati Kérdôívet (Bartholomew és Horowitz, 1991). A kultúrák 79\%-ában a biztonságos kötôdés volt a normatív, ugyanakkor a szorongó kötôdés a kelet-ázsiaiakat inkább jellemezte. Ezek a különbségek szoros kapcsolatban lehetnek a kölcsönösen függó és független én-konstrukció kulturális dimenziójával (Markus és Kitayama, 1991). A kölcsönösen függó szelf-konstrukcióval összefüggó kötôdés tökéletesen érettnek és egészségesnek tekintett a kelet-ázsiai kultúrában, ugyanakkor félreérthetô az ame- 
rikai, független én-konstrukciót idealizáló világban. Az amerikaiak számára a társas kapcsolatokba szorosan beágyazott én, az én „elvesztése” összefolyásnak, énhatárok nélküliségnek, az elhagyatottság középpontba helyezésének tûnik. A kelet-ázsiaiak tartózkodása attól, hogy nyíltan feltárják az érzelmeiket, vagy segítséget kérjenek, könnyen értelmezôdik úgy, hogy elkerülóen kötődnek. Vagyis az, ami a kelet-ázsiai kultúrában kulturálisan adaptív, egészséges és része lehet a normatív tartománynak, a nyugati pszichiátriában a pszichopatológiával kapcsolódik össze (Mikulincer és Shaver, 2012). Wang és Mallincrodt (2006) felhívják a figyelmet arra, hogy ezeket az eredményeket annak bizonyítékául kell tekinteni, hogy az ideális kötôdésnek nagyon különbözô kifejezései lehetnek a különbözô kultúrákban. Ezért az eltérô kultúrkörbôl származó tanácsadónak vagy például párterapeutának tisztában kell lennie ezekkel a különbségekkel.

Az idôskori kötôdés kutatása még napjainkban is gyerekcipóben jár. Magai és munkatársai (Magai, Cohen, Milburn, Torpe, McPherson és Peralta, 2001) vizsgálata talán az egyetlen, amelyik a Kapcsolati Stílus Kérdôív eredményeit (Griffin és Bartholomew, 1994) két különböző amerikai etnikai csoportban, az európai-amerikaiban és az afrikai-amerikaiban idôs embereken hasonlította össze. Az európai-amerikai és az afrikai-amerikai csoport összehasonlítását az indokolta, hogy bár mindkét csoport komoly nehézségeket élt át fiatal korában (háború, gazdasági válság), az afrikai-amerikai csoport nagyobb deprivációban élt, és a faji megkülönböztetést is el kellett szenvednie. Bár a fiatal felnôttekéhez képest mindkét csoportban jóval alacsonyabb volt a biztonságosan kötôdôk aránya és jóval magasabb az elutasítóké, ez az arány méginkább jellemezte az afrikai-amerikai idôseket. A szerzôk magyarázata szerint a felnôtt kötôdési mintákra erôteljesen hatnak az egyént az élete során érô társadalmi-gazdasági hatások is.

\section{A KULTURÁLIS KONTEXTUS JELENTOOSÉGE}

A kötôdés kulturális különbségeit univerzalista megközelítésból kutatók azt hangsúlyozzák, hogy a kulturális különbségek viszonylag kicsik és jelentéktelenek (van IJzendoorn és Sagi-Schwartz, 2008; Hámori, 2015). Ezzel szemben az úgynevezett „émikus” kulturális összehasonlítás mellett érvelő kutatók nagyobb jelentôséget és formáló erôt tulajdonítanak a kultúrának. Ezek a kutatók arra az álláspontra helyezkedtek, hogy a kötôdés elmélete, a kötôdési mintázatok kategorizációja, az anyai érzékenység értékelése, valamint a kötôdési mintázatok késôbbi személyiségfejlôdésre gyakorolt hatásának elképzelése mind a nyugati, középosztálybeli anya-gyerek diádra kidolgozott elméletek és értékelô rendszerek, amelyek alapvetốn etnocentrikusan közelítenek a kötôdés jelenségéhez (Rothbaum és mtsai, 2000; Keller, 2013, 2016). Rothbaum (2000) szerint a nyugati kutatók vakok az emberi kapcsolati mintázatok nyugati kultúrától eltérô megnyilvánulásaival szemben, mert más kultúrákat nyugati ideálokkal és prekoncepciókkal ruháznak fel. Keller (2013) szerint a kötôdés generációról generációra történô átadása, a deviációk és a patológiák diagnosztizálása azon a feltevésen alapulnak, hogy a gyermek monotrópikus kapcsolatot alakít ki egy gondozóval, kizárólagos figyelmet kap a gondozótól, aki leginkább az anya, és aki 
szenzitíven reagál a csecsemô jelzéseire. Az egészséges gyermeki személyiségfejlődés eredményének az autonóm, individualista egyént tartják (Rothbaum és mtsai, 2000). Ezek a feltevések a világ népességének kevesebb, mint 5\%-át kitevô nyugati középosztálybeli családok szülő-gyerek kapcsolatát jellemzik. Ez a csecsemố-gondozó kapcsolat véleményük szerint csak azokban a közegekben lehet adaptív, amelyekben bôségesen állnak az anyagi és a társas eróforrások rendelkezésre, és ezért a családok „megengedhetik maguknak” a gondozó-gyermek szenzitíven egymásra hangolódó diádját (LeVine, 1988; Keller, 2013). A fejlôdési ideálok alapvetôen az individualista kulturális elvárásokat tükrözik.

Rothbaum és Morelli (2005) a fentiek alapján az émikus megközelítést javasolják a kötődési folyamatok megértésére (116): „Az elônye az émikus megközelítéseknek amelyek a helyi hagyományokra és a kutatott népek számára nagyobb jelentôséggel bíró gyakorlatokra fókuszálnak -, hogy a viselkedésról annak kontextusában nyújtanak képet, és, hogy jelentést adnak az emberi múködés változatosságának.”

Bretherton (1985) két korai példát hoz arra, hogy a kötôdési mintázatok hogyan függhetnek össze eltérô szocializációs célokkal. Ezek a kutatások bôven megeloozték Bowlbyék munkásságát, és pusztán antropológiai igénnyel, megfigyeléses módszerrel folytak a `30-as, `40-es években. Két, a kötôdést nagyon különbözően értelmezó és szocializáló népcsoportot mutat be: a mikronéziai Tikopia törzset (Firth, 1936, idézi Bretherton, 1985) és egy bali faluközösséget (Mead és Bateson, 1942, idézi Bretherton, 1985). Alapvetô különbség mutatkozott a két nép között kötôdéssel kapcsolatos szokásaikban, attitűdjükben. A fizikai kontaktus mindkét népcsoportnál gyakori volt. A Tikopia törzsnél a nyugati klasszikus kötôdés motívumai voltak megtalálhatók: a gyermek nyugodt maradt a gondozó mellett, feldúlta annak távozása, és veszély esetén a gondozóhoz fordult. Ugyanakkor az anya mellett több gondozóval is kialakított a gyermek szoros kötôdést. A bali népcsoportnál azt találták, hogy az anya szándékosan, félelmetes hangokkal ijesztgette a gyermeket, hogy az felkészüljön a veszedelmekre. Emellett az anyák kifejezetten arra szocializálták a gyerekeket, hogy azok ne vonódjanak be könnyen érzelmi kapcsolatokba. Például vidám játékba vonták a gyereket, de amint az élvezni kezdte azt, az anya üres tekintettel közömbösen visszahúzódott. A gyerekek megtanulták, hogy ne reagáljanak az ilyen kezdeményezésekre. A Tikopia törzs esetében a nyílt érzelemkifejezés része volt a kötôdés kifejezésének, a bali népcsoportnál viszont az anya akkor alakított ki kulturálisan elfogadott kötôdést, ha az érzelmek nem fejezôdtek ki, az anyai érzékenység épp azt tanította meg, hogy az anya és a gondozó, vagyis a külvilág nem érzékeny és nem lehet tôle várni szenzitív válaszokat. Az anya gondosan, szisztematikusan és felelôsségteljesen foglalkozott a gyerekkel, figyelt annak érzelmi reakcióira, de épp arra szocializálta, hogy a világ félelmetes, ne bízzon meg benne és ne kapcsolódjon másokhoz érzelmileg. E két példán jól látható, hogy mindkét esetben az anyák felelôsek és gondosak, és szívükön viselik a gyermek szocializációját, de a nyugati klasszifikáció szerint az egyik esetben az anya biztonságos kötôdést alakít ki, a másik esetben elkerülô kötôdést, amelyet a nyugati szakirodalom maladaptívnak tekint (Keller, 2013). Ez a klasszifikáció azonban valójában azt jelezné, hogy csak a felszínét ragadjuk meg az anya-gyerek kapcsolatnak, és nem a valódi jelentéstartalmát, amely az anyai elfogadást paradox módon éppen a kötôdés nem mutatásához köti (Bretherton, 1985). 


\section{Az anya-gyerek kapcsolat monotropizálódása}

Heidi Keller (2013) szerint az univerzalitást valló kutatók számos lényeges tényezôt kevéssé vesznek tekintetbe. Ezek egyike a csoportos gondozás. Van IJzendoorn és SagiSchwartz (2008) azt állítják, hogy bár sok kultúrában a gyerekek a kötődési személyek hálózatában nônek, mégis az a szülô vagy gondozó, aki a nap egy részében vagy éjszaka felelôsséget vállal a gyerek gondozásáért, a gyerek kiemelt kötôdési tárgyává válik. Ahogyan Bowlby (1969) nevezte, a kötôdési viselkedés egy személyre monotropizálódik. Keller (2013) megkérdójelezte, hogy a monotropizálódás jelensége kulturálisan univerzális lenne. Véleménye szerint a gyermekgondozásban az egyik legnyilvánvalóbb kulturális különbség az, hogy van-e egy kiemelt elsôdleges gondozó - amely a világ kisebbségére jellemzô -, vagy a gyermeket többen látják el, és senki nem játszik egyértelmúen kiemelt szerepet. Hrdy (2007) amellett érvelt, hogy az emberiség nem maradt volna fenn, ha egy kisgyermeket csak egy kiemelt gondozó látott volna el. Primáták megfigyelése során kialakított kooperatív nevelési modellje szerint a társas csoport olyan tagjai, akik a kölyökkel nem állnak közvetlen biológiai kapcsolatban, azonos intenzitással viselik gondját, mint a közvetlen hozzátartozói. Az állatvilágból említ olyan példákat, amelyekben a nevelési szokások különbségei a „kötődés” variációihoz vezettek: Bowlby (1973) rézusz majmokkal kapcsolatos vizsgálatokra (pl. Hinde, Bowell és Spencer-Booth, 1964) alapozta a kötôdéssel kapcsolatos elméletét, de ennél a fajnál nem jellemzó a kooperatív nevelés, és az anya kizárólagos szerepet játszik az utódgondozásban. Hrdy (2007) ezért kritikával szemlélte Bowlby munkáját. A primáták esetében nagyon különbözôek az utódgondozási mintázatok. A közönséges hulmánok esetében például a kicsinyeket a nap legalább felében nem az anya, hanem egy másik személy ốrzi. Náluk is jellemzô ugyan, hogy a kicsinyek lármáznak, ha szem elôl tévesztik az anyjukat, ugyanakkor mégis hozzá vannak szokva mások jelenlétéhez. Hrdy szerint elképzelhetô, hogy árnyaltabb kép alakult volna ki a kötôdés jelenségérôl, ha Bowlby nemcsak Harlow és Hinde munkájára alapozza elméletét, illetve ha ốk más fajokon is elvégezték volna a megfigyeléseiket és kísérleteiket. Számos olyan adatot mutat be, amelyek alátámasztják, hogy az olyan közösségekben, ahol a gyermekhalandóság magas, illetve a környezet eltartó képessége alacsony, sokkal több esélye van egy gyermeknek az életben maradásra, illetve az anyának a reproduktív sikerességre, ha a nevelés mások segítségével folyik. A kooperatív nevelés hatására a csecsemô érzékeny lesz nemcsak az anya jelzéseire, hanem az anyahelyettesítókére is, és hasonlóképpen keres másoknál is biztonságot, mint az anyánál. Ez a fajta gondozási elrendezés számos embercsoport esetében ugyancsak jellemzó, és bizonyos csoportokban meghaladhatja a huszat is azoknak a száma (testvérek, rokonok, szomszédok), akik a csecsemót rendszeresen gondozzák (Keller, 2013). Keller és Otto (2011) vizsgálatai szerint a kameruni nso anyák kifejezetten igyekeznek elkerülni, hogy a gyerek speciális kötôdést alakítson ki velük, ezért például ráfújnak az arcára, hogy elfordítsa a fejét és másokra is figyeljen. Az érzelmi kötôdés ezekben a kultúrákban meglehetôsen diffúz, a biztonság és a pszichés jóllét nem koncentrálódik egyetlen meghatározott emberre, az anyára (Keller, 2013). A 2. táblázat bemutatja, hogy Keller (2016) milyen lényeges különbségeket lát a csoportos gondozás és a diádikus gondozás között. 
2. táblázat. A csoportos gondozás és a diádikus gondozás összehasonlítása

\begin{tabular}{|c|c|c|}
\hline & Csoportos gondozás & Anya-gyerek diád \\
\hline monitorozás & $\begin{array}{l}\text { folytonosan monitorozva van } \\
\text { a csecsemô }\end{array}$ & néha megszakad a monitorozás \\
\hline válaszkészség & gyorsabb reakció az igényekre & késleltetett reakció az igényekre \\
\hline kommunikáció & $\begin{array}{l}\text { proximális kommunikációs csator- } \\
\text { nák (pl. testkontaktus) }\end{array}$ & $\begin{array}{l}\text { disztális kommunikációs csatornák } \\
\text { (beszéd) }\end{array}$ \\
\hline biztonság & több forráshoz köthetố a biztonság & egy forráshoz köthetố a biztonság \\
\hline nevelés célja & $\begin{array}{l}\text { cél a jólnevelt, társadalomba bele- } \\
\text { simuló ember }\end{array}$ & cél az önálló, önérvényesítô ember \\
\hline
\end{tabular}

Az eltéró gondozói környezet eltérô kutatási módszerek alkalmazását igényli. Az anyai szenzitivitás mérésére eredetileg kifejlesztett skálát nem lehet többszörös gondozójú kultúrában alkalmazni. Mesman és munkatársai (Mesman, Minter és Angnged, 2016) ezért átalakították a mérôeszközt úgy, hogy a mérés középpontjába a csecsemôt helyezték: azt nézték, hogy egy megfigyelési idôszak alatt hány érzékeny választ kap, függetlenül attól, hogy az 1 vagy 15 gondozótól jön. Így a különbözó kultúrák numerikusan összehasonlíthatóvá váltak a szenzitív gondozói válaszok tekintetében.

A kultúraközi vizsgálatok tanulságai szerint a biztonságos kötôdés kialakulása nem kötôdik feltétlenül egy kiemelt személlyel való kapcsolathoz, hanem ezt a kisgyermek igényeit tekintetbe vevô, többszörös gondozói közeg is maradéktalanul meg tudja teremteni.

\section{A szocioökonómiai környezet szerepe}

Keller (2013) a gazdasági környezet jelentőségére is felhívta a figyelmet: a középosztálybeli környezet, amelyben a kötốdéskutatások legnagyobb része zajlott, egészen más értéket tulajdonít a gyermeknek, mint az a környezet, amelyben a gyermekek túlélése az elsôdleges cél. Keller Robert LeVine munkáit idézi. Robert LeVine 1974-ben a kultúra és nevelés összefüggésével kapcsolatban egy hierarchikus modellt állított fel, és a benne foglaltak erôsen kapcsolódnak a kötôdés kulturális változatosságához (LeVine, 1974, 1988, Rogoff, 2003). A modell szerint a szülôknek három fontos célja van a gyermek nevelésekor: az elsô a gyermek túlélése, a második a boldogulásához szükséges anyagi javak megteremtése és a harmadik a kulturális értékek átadása. Az olyan környezetben, melynek gazdasági eltartó képessége alacsony és a gyermekhalandóság magas, ott a gondozónak nem érdemes szoros kötôdést kialakítani a gyenge csecsemôkkel, ezért gyakori, hogy sorsukra hagyják óket. Viszont szoros, proximális kötôdést kell kialakítani az erôsekkel, hogy maximalizálják a túlélési esélyeket. A nyugati, biztos gazdasági hátterú környezetekben, ahol kevéssé fenyeget az a veszély, hogy a gyermeket korán elveszíthetik, és gyakori, hogy egy házaspárnak csak egy gyermeke van, nincs hatása a gyermek életképességének a kötôdésre. 
A kötốdés egyik alapfogalma az anyai szenzitivitás (Ainsworth, Blehar, Waters, Will, 1978), amelynek két mutatója az anyai reakció idôbelisége és adekvátsága, a megfelelố idôben érkezô megfelelố válasz. Rothbaum és Morelli (2005) szerint az, hogy mi az „idôben” és mi a „megfelelô”, jelentôsen különbözik kulturális kontextusonként. Ezeknek a jellemzóknek a jelentése és értelmezése nagyon eltérô lehet. Így például az érzékenység reaktív/válaszjellegú felfogása erôsen különbözik a számos kultúrában megnyilvánuló proaktív-preventív anyai magatartástól. Az anyák válaszkészségét úgy mérik a kötôdésvizsgálatok, hogy milyen gyorsan reagál az anya a gyerek jelzéseire (reaktív magatartás). Míg más kultúrákban sokkal inkább az jelzi az anyai érzékenységet, hogy mennyire tudja anticipálni a gyerek reakcióját, mielôtt az bekövetkezne, és mennyire tudja azt megelôzni (preventív/proaktív). A japán anyáknál sokkal inkább ezt a proaktív, a distressz kialakulását megelôzô anyai magatartást figyelték meg, és nem annyira a már bekövetkezett distressz kezelését (Trommsdorff és Friedelmayer, 2010). A reaktív anyai magatartás, amely arra vár, hogy a gyerek kezdeményezzen, az individualista kulturális közegben adaptív. A preventív anyai magatartás ezzel szemben a környezethez való akkomodációt erôsíti a gyerekben, és azokban a kultúrákban adaptív, ahol nem cél az önérvényesító egyén mint ideális embertípus. Például a szülói kontrollt az autonóm, asszertív egyént mint ideális nevelési célt kitúzô nyugati kultúrában a bizonytalan kötốdéssel hozzák összefüggésbe. Ugyanez a szülối magatartás viszont biztonságos kötôdéshez vezet azokban a társadalmakban, ahol a nevelési cél a környezetéhez illeszkedô és alkalmazkodni tudó egyén. Carlson és Harwood (2003) azt találták, hogy Puerto Ricó-i anyák sokkal több fizikai kontrollt gyakoroltak a csecsemôgondozásuk során, mint az európai-amerikai anyák, és ez a szoros fizikai kontroll biztonságosabb kötôdéshez vezetett az ô esetükben. Ezzel szemben az euro-amerikai gyerekeknél az erôsebb fizikai kontroll elkerülố kötôdést eredményezett. A nyugati anyák a gyerek pozitív jelzéseire reagálnak, a guszi anyák inkább a gyerek negatív reakcióira, és ha a gyerek pozitívan izgatott, akkor inkább elfordulnak tôle, hogy ezzel nyugtassák (LeVine, 2004). Az anyai szenzitivitás mindkét esetben szükséges ahhoz, hogy a gyerek a saját társadalmi közege elvárásainak megfeleljen, de a kapott fejlốdési eredmény más. Ainsworth kijelentése (Ainsworth, 1976), miszerint az anyai szenzitivitás a gyerek autonómiáját erôsíti, csak a nyugati kultúrkörben állja meg a helyét. Rothbaum és munkatársai (2000) szerint, amit a nyugati kutatók az ambivalens kötôdés megnyilvánulásának tekintenek, azt Japánban az amae megnyilvánulásának tartják. Ez a japán kultúrában tökéletesen elfogadott, és nem a bizonytalan kötốdés jelzése.

\section{A különbözö kultúrák eltérô szocializációs céljai}

Rothbaum és munkatársai (2000) a szelf kulturális meghatározottságának és az anyagyermek kapcsolat egy-egy kultúrában kialakult sajátos formáinak a jelentôségére hívja fel a figyelmet. A klasszikus kötődéselmélet kompetenciahipotézise szerint a biztonságosan kötôdố gyerekek autonómabbak, kevésbé dependensek. Mi a helyzet azokkal 
a kultúrákkal, ahol nem cél az autonóm és független egyén nevelése, hanem éppen ellenkezôleg, a társas közegével szoros kölcsönös függésben és dependenciában egzisztálni tudó egyén, ami utóbbi a pszichés érettség képviselôje? Ainsworth (1976) anyai szenzitivitást mérô skáláján ilyen, kulturálisan egyértelmúen egyoldalú szempontok szerepelenek, mint „az anya értékeli azt a tényt, hogy a gyereknek saját akarata van, még akkor is, ha ellentmond neki [...] tiszteletben tartja a csecsemốt mint egy szeparált, autonóm személyt" (Ainsworth, 1976, 4, idézi Rothbaum és mtsai, 2000). Rothbaum és munkatársai (2000) Ainsworthszel szemben arra hívják fel a figyelmet, hogy különböző ökológiai közegek eltérô én-felfogáshoz vezetnek, és ennek szintén vannak következményei a kötôdésre vonatkozóan. Az, hogy egy kultúra milyen módon gondolkodik az én fogalmáról, azaz azt egy kölcsönösen függó vagy épp független entitásként konstruálja-e meg, meghatározza a kötôdés jellegzetességeit. A japán Idegen Helyzet vizsgálatok rendre azt eredményezték, hogy a bizonytalan-ambivalens kötődés felülreprezentált, az elkerülő kötôdés viszont alulreprezentált (Miyake, Chen és Campos, 1985; Takahashi, 1986). Ez szoros kapcsolatban áll az amae (Doi, 1989) jelenségével (Rothbaum és mtsai, 2000). Az amae az anyára való rátámaszkodást, függôséget fejezi ki. Ez a fajta kapcsolódás a felnôttkori társas kapcsolataiban is tovább él. Az elérni vágyott kompetencia a gyermekeknél a kölcsönös függésre való képesség és engedelmesség, nem pedig a nyugati kultúrákban magasra értékelt önállóság, függetlenség és autonómia (Rothbaum és mtsai, 2000, 2007). Az euro-amerikai középosztálybeli kultúrában klinikai problémának tekintik az anya és csecsemôje közötti szimbiotikus kapcsolat továbbélését, amely számos nem-nyugati kultúrában viszont kulturális sztenderd (Keller, 2013). A korábban ismertetett vizsgálati eredmények, melyek szerint a kelet-ázsiai kultúrákban nagyobb arányban fordul elố a szorongó-ambivalens kötôdés (Wang és Mallinckrodt, 2006), szintén összhangban vannak a kölcsönösen függó én-modellel és a környezet erre vonatkozó elvárásaival. Rothbaum és munkatársai interjúsmódszerrel (2007) igyekeztek feltárni a japán és amerikai kötôdési mintázatok között talált eltérések kulturális gyökereit. Azt emelték ki, hogy míg Amerikában a kötôdés és a világ felfedezése egymással ellentétes motivációk, és a legfóbb aktuális feladat a kettố közti egyensúly megtalálása, addig Japánban a kölcsönös függés, az interperszonális egység a legfőbb cél, az exploráció nem támogatott. Míg az amerikaiak számára az egyéni potenciálok kiteljesítése lesz hosszú távon az elsôdleges cél, addig a japánoknak olyan felnôttek nevelése, akik harmonikusan tudnak együtt élni a környezetükkel. Carlson és Harwood (2003) korábban ismertetett Puerto Ricó-i vizsgálata azt bizonyítja, hogy ugyanaz az anyai magatartás (kontrolláló) az egyik kultúrában biztonságos, a másikban elkerülô kötôdéshez vezet, összhangban az adott kultúra szocializációs céljaival. Ugyanakkor egy-egy kötôdési típus nem ugyanazokkal a viselkedéses reakciókkal jár együtt egymástól eltérô kultúrákban. A mainstream kötôdéselmélet szerint a biztonságosan kötôdô gyerek barátságosabb az ismeretlenekkel, mint a bizonytalanul kötôdô. Egy olyan kultúrában (ilyen minden kollektivista kultúra), amelyben éles különbséget tesznek a saját csoport és a külsô csoport között, azonban sokkal inkább elvárják az anyák, hogy a gyerek barátságos legyen az idegenekkel. Vagyis a gyerek tartózkodása ismeretlen személyekkel szemben semmilyen módon nem tükrözi a kötôdése biztonságát (Rothbaum és mtsai, 2000). 


\section{AZ EVOLÚCIÓELMÉLET ÉS A KULTURÁLIS HATÁSOK ÖSSZEBÉKÍTÉSE}

Keller (2013) egy evolúciós alapú, de kulturálisan is megalapozott kötôdéselméletet javasol, amely összhangban van Belsky (1999) nézeteivel. A kulturális különbségek valójában a környezethez való adaptációk, vagyis evolúciós stratégiák. Rothbaum és munkatársai (2000) a kötôdés kulturális meghatározottságát azonos jelentôségúnek tartják a biológiai meghatározottságával. Az euro-amerikai középosztálytól eltérô kulturális miliôben növekvő gyerekek másképp válnak felnôtté. Nem létezik egyetlen olyan kapcsolati modell sem, amely az egyedüli adaptív a világ teljes népességére nézve. Belsky (1999) azt hangsúlyozta, hogy a különbözô kötődési mintázatok nem egy egészséges (biztonságos) és további két „aberrált” (elkerülő, szorongó-ambivalens) stratégiából állnak, hanem ezek a stratégiák különböző környezeti feltételekhez történô adaptációs kihívások adaptív válaszai. Ezért a biztonságos kötôdés nem „jobb”, mint az elkerülố vagy a szorongó-bizonytalan, hanem egy másik formája a túlélés maximalizálásának. Azt a kérdést, hogy mi a normatív egy társadalomban, illetve egy csoportban a kötôdési stílusokat illetôen, Ein-Dor és Hirschberger (2016) a következôképpen válaszolták meg: annál inkább képes túlélni vagy jól múködni egy csoport, minél színesebb tagokból áll, tehát egy jó társadalomban mindegyik kötôdési stílus egyaránt képviselteti magát, így növelvén az adott társadalom fitneszét.

\section{KÖVETKEZTETÉSEK}

Rothbaum és Morelli (2005) megfogalmazott egy négy pontból álló módszertani iránymutatást a kultúraközi kötôdéskutatással foglalkozó szakembereknek annak érdekében, hogy elkerüljék az érvénytelen konklúziók levonását. Eszerint törekedni kell a különbözô módszerek (etnográfia, megfigyelés, interjú, kontrollált laboratóriumi vizsgálatok) széles skálájának az alkalmazására, mert mindegyik más elônyével tud hozzásegíteni a pontos megismeréshez. Törekedni kell a különbözô kultúrájú kutatók és a kutatást segítô helyi lakosok közti kooperációra az etnocentrikus torzítások leküzdése érdekében. A harmadik tanács, hogy a kutatónak alaposan meg kell ismerkednie a szóban forgó kultúrával, hogy meg tudja érteni a kutatott folyamatok dinamikáját. Végül pedig nyitottnak és naprakésznek kell lenni az új módszertani lehetóségek irányában.

E négy ponton kívül meglátásunk szerint még egy szempontot elengedhetetlen figyelembe vennie a kutatónak. Mégpedig azt, hogy kulturális feltáró kutatást vagy kulturális összehasonlító kutatást szándékozik-e folytatni. Előbbi esetben ugyanis az émikus, mélyen feltáró megfigyelések, interjúk stb. a legcélravezetôbb módszerek, míg utóbbi esetben, mivel szükség van valamilyen közös inerciarendszerre, ezért tetszôleges mértékig ugyan, de célszerû lemondani a mély megismerésrôl a közös értelmezés érdekében. Természetesen émikus módszerekkel is lehet összehasonlítást végezni, ám a jelenségek komplex megragadásából kifolyólag az összehasonlítás kritériumainak a kijelölése erôsen megnehezül.

John Bowlby és Mary Ainsworth világosan kifejtették, hogy a kötôdés a gyerekek fejlődésének biopszichológiai szükséglete. Az azonban, hogy kivel alakul ki kötôdés, milyen módon nyilvánul meg és az, hogy mi adaptív és maladaptív, kulturálisan meg- 
határozott. Ha egy kulturális közeg a negatív érzelmek elnyomását kívánja meg, akkor a csecsemôk elkerülô kötôdési mintázatot mutathatnak azért, hogy megfeleljenek ennek a kívánalomnak. Egy ilyen kultúrában az elkerülô mintázat normatív lehet abban az értelemben, hogy növeli az inkluzív fitnesszt, és az általános adaptációt szolgálja. Az is bonyolult kérdés, hogy mindaz a magatartásforma, amit a kutatók sztenderd módon az elkerülés jelének tekintenek, valóban azt jelenti-e más kultúrákban. A kötôdés univerzális volta, amelyet egyetlen kutató sem von kétségbe, csak azt jelenti, hogy valamilyen kötôdés ki fog alakulni minden egyes kultúrában, függetlenül a gyermeknevelés kialakult gyakorlatától és a családi struktúrától. Ugyanakkor nem jelenti azt, hogy a fô kötôdési mintázatok univerzálisan normatívak. Ebbôl következôen a jelenlegi globalizált világban nem lehet olyan szülői intervenciós programot vagy terápiás beavatkozást végezni, amelyik nem kulturálisan érzékeny és informált, és amely esetében felmerülhet annak a veszélye, hogy egy, az adott kultúrában egészséges és adaptív pszichés konstellációt kulturális vakságból és tudatlanságból patologizál.

\section{IRODALOM}

Ainsworth, M. D. S. (1976). System for rating maternal care behavior. Princeton, NJ: ETS Test Collection.

Ainsworth, M. D. S., Blehar, M. C., Waters, E., \& Wall, S. (1978). Patterns of attachment: A

psychological study of the strange situation. Hillsdale, NJ: Erlbaum.

Armsden, G. C., \& Greenberg, M. T. (1987). The inventory of parent and peer attachment: Individual differences and their relationship to psychological well-being in adolescence. Journal of Youth and Adolescence, 16(5), 427-454.

Atkinson, L. (1997). Attachment and Psychopathology: From Laboratory to Clinic. In L. Atkinson, \& K. J. Zucker. (Eds.), Attachment and Psychopathology (pp. 3-16). New York: Guilford Press.

Bartholomew, K., \& Horowitz, L. M. (1991). Attachment styles among young adults: a test of a four-category model. Journal of Personality and Social Psychology, 61(2), 226-244.

Belsky, J. (1999). Interactional and contextual determinants of attachment security. InJ. Cassidy, \& P. R. Shaver (Eds.), Handbook of attachment: Theory, research, and clinical applications (pp. 249-264). New York, NY, US: Guilford Press.

Bowlby, J. (1951). Maternal care and mental health. Geneva: World Health Organization Monograph.

Bowlby, J. (1969). Attachment and loss, Vol. 1. Attachment. London: Hogarth Press

Bowlby, J. (1973). Attachment and loss, Vol. 2: Separation. London: Hogarth Press.

Bowlby, J. (1979). The making and breaking of affectional bonds. Hove and New York: BrunnerRoutledge.

Bowlby, J. (1980). Attachment and loss, Vol. 3: Loss, sadness and depression. London: Hogarth.

Brennan, K. A., Clark, C. L., \& Shaver, P. R. (1998). Self-report measurement of adult romantic attachment: An integrative overview. In J. A. Simpson, \& W. S. Rholes (Eds.), Attachment theory and close relationships (pp. 46-76). New York: Guilford Press.

Bretherton, I. (1985). Attachment theory: Retrospect and prospect. Monographs of the Society for Research in Child Development, 50(1-2), 3-35.

Bretherton, I. (1992). The origins of attachment theory: John Bowlby and Mary Ainsworth. Developmental Psychology, 28(5), 759-775. 
Carlson, V. J., \& Harwood, R. L. (2003). Attachment, culture, and the caregiving system: The cultural patterning of everyday experiences among Anglo and Puerto Rican mother-infant pairs. Infant Mental Health Journal, 24(1), 53-73.

Ditommaso, E., Brannen, C., \& Burgess, M. (2005). The universality of relationship characteristics: A cross-cultural comparison of different types of attachment and loneliness in Canadian and visiting Chinese students. Social Behavior E Personality, 33, 57-68.

Doi, T. (1989). The concept of amae and its psychoanalytic implications. International Review of Psycho-analysis, 16(3), 349-354.

Durrett, M. E., Otaki, M., \& Richards, P. (1984). Attachment and the mother's perception of support from the father. International Journal of Behavioral Development, 7(2), 167-176.

Ein-Dor, T., \& Hirschberger, G. (2016). Rethinking Attachment Theory From a Theory of Relationships to a Theory of Individual and Group Survival. Current Directions in Psychological Science, 25(4), 223-227.

Feeney, J. A., Noller, P., \& Hanrahan, M. (1994). Assessing adult attachment.In M. B. Sperling \& H. Berman (Eds.), Attachment in adults: Clinical and developmental perspectives (pp. 128-152). New York, NY, US: Guilford Press.

Firth, R. (1936). We, the Tikopia: kinship in primitive Polynesia. Boston: Beacon.

Gernhardt, A., Keller, H., \& Rübeling, H. (2016). Children's Family Drawings as Expressions of Attachment Representations Across Cultures: Possibilities and Limitations. Child Development.87(4), 1069-1078.

Griffin, D. W., \& Bartholomew, K. (1994). The metaphysics of measurement: The case of adult attachment. In K. Bartholomew, \& D. Perlman (Eds.), Advances in personal relationships: Vol. 5. Attachment processes in adulthood (pp. 17-52). London: Jessica Kingsley.

Grossmann, K. E., Grossmann, K., Huber, F., \& Wartner, U. (1981). German children's behavior towards their mothers at 12 months and their fathers at 18 months in Ainsworth's Strange Situation. International Journal of Behavioral Development, 4(2), 157-181.

Grossmann, K., Grossmann, K. E., Spangler, G., Suess, G., \& Unzner, L. (1985). Maternal sensitivity and newborns' orientation responses as related to quality of attachment in northern Germany. Monographs of the Society for Research in Child Development, 50(1-2), 233-256.

Hámori E. (2015). A kötődéselmélet perspektívái. A klasszikusoktól napjainkig. Budapest: Animula.

Hámori, E., Dankháziné Hajtman, E., Urbán, Sz., Martos, T., Kézdy, A., \& Horváth-Szabó, K. (2016). A felnôtt kötődés új típusai? Eredmények a Kötôdési Stílus Kérdőívének magyar változatával (ASQ-H). Alkalmazott Pszichológia, 16(3), 57-77.

Hinde, R. A., \& Stevenson-Hinde, J. (1990). Attachment: Biological, cultural, and individual desiderata. Human Development, 33, 62-72.

Hinde, R. A., Bowell, T., \& Spencer-Booth, Y. (1964). Behaviour of socially living rhesus monkeys in their first six months. Proceedings of the Zoological Society of London, 14(4), 609-649.

Hrdy, S. B. (2007). Evolutionary context of human development: The cooperative breeding model. In C. A. Salmon, \& T. K. Shackleford (Eds.), Family relationships: An evolutionary perspective (pp. 39-68). Oxford: Oxford University Press.

Keller, H., \& Otto, H. (2011). Different faces of autonomy. In X. Chen, \& K. H. Rubin (Eds.), Socioemotional development in cultural context (pp. 164-185). New York, NY, US: The Guilford Press.

Keller, H. (2013). Attachment and culture. Journal of Cross-Cultural Psychology, 44(2), 175 -194.

Keller, H. (2016). Attachment. A pancultural need but a cultural construct. Current Opinion in Psychology, 8, 59-63.

Kermoian, R., \& Leiderman, P. H. (1986). Infant attachment to mother and child caretaker in an East African community. International Journal of Behavioral Development, 9(4), 455-469. 
LeVine, R. A. (1974). Parental goals: A cross-cultural view. Teachers College Record, 76(2), 226-239.

LeVine, R. A. (1988). Human parental care: Universal goals, cultural strategies, individual behavior. New Directions for Child and Adolescent Development, 40, 3-12.

LeVine, R. A. (2004). Challenging expert knowledge: Findings from an African study of infant care and development. In U. P. Gielen \& J. Roopnarine (Eds.), Childhood and adolescence: Cross-cultural perspectives and applications. (pp. 149-165).

Magai, C., Cohen, C., Milburn, N., Torpe, B., McPherson, R., \& Peralta, D. (2001). Attachment styles in older European American and African American adults. Journal of Gerontology, 56(1), S28-S35

Markus, H. R., \& Kitayama, S. (1991). Culture and the self: Implications for cognition, emotion, and motivation. Psychological Review, 98(2), 224-253.

Marvin, R., van Devender, X, Iwanaga, M., Levine, S., \& Levine, R. (1977). Infant-caregiver attachment among the Hausa of Nigeria In H. McGurk (Ed.), Ecological factors in human development (pp. 247-260). Amsterdam: North Holland.

Mead, M., \& Bateson, G. (1942). Balinese character. New York: New York Academy of Sciences.

Mesman, J., Minter, T., \& Angnged, A. (2016). Received sensitivity: adapting Ainsworth's scale to capture sensitivity in a multiple-caregiver context. Attachment $\mathcal{E}$ Human Development, 18(2), 101-114.

Mikulincer, M., \& Shaver, P.R. (2012). An Attachment Perspective on Psychopathology. World Psychiatry, 11(1), 11-15.

Miyake, K., Chen, S. J., \& Campos, J. J. (1985). Infant temperament, mother's mode of interaction, and attachment in Japan: An interim report. Monographs of the Society for Research in Child Development, 50(1-2), 276-297.

Nguyen Luu, L. A. (2003). Lehet-e összehasonlító a pszichológia, ha kulturális. In Fülöp M. \& Nguyen Luu, L. A. (szerk.), Kultúra és pszichológia (pp. 15-53). Budapest: Osiris kiadó.

Posada, G., Gao, Y., Wu, F., Posada, R., Tascon, M., Schöelmerich, A., ... \& Synnevaag, B. (1995). The secure-base phenomenon across cultures: Children's behavior, mothers' preferences, and experts' concepts. Monographs of the Society for Research in Child Development, 60(2-3), $27-48$.

Rogoff, B. (2003). The cultural nature of human development. Oxford University Press.

Rothbaum, F., Weisz, J., Pott, M., Miyake, K., \& Morelli, G. (2000). Attachment and culture: Security in the United States and Japan. American Psychologist, 55(10), 1093-1104.

Rothbaum, F., \& Morelli, G. (2005). Attachment and culture: Bridging relativism and universalism.In W. Friedlmeier, P. Chakkarath \& B. Schwarz (Eds.), Culture and human development: The importance of cross-cultural research for the social sciences (pp. 99-124). Hove and New York: Psychology Press.

Rothbaum, F., Kakinuma, M., Nagaoka, R., \& Azuma, H. (2007). Attachment and Amae Parent-Child Closeness in the United States and Japan. Journal of Cross-Cultural Psychology, 38(4), 465-486.

Sagi, A., Lamb, M. E., Lewkowicz, K. S., Shoham, R., Dvir, R., \& Estes, D. (1985). Security of infant-mother,-father, and-metapelet attachments among kibbutz-reared Israeli children. Monographs of the Society for Research in Child Development, 50(1-2), 257-275.

Schmitt, D. P., Alcalay, L., Allensworth, M., Allik, J., Ault, L., Austers, I., .. \& Braeckman, J. (2004). Patterns and Universals of Adult Romantic Attachment Across 62 Cultural Regions Are Models of Self and of Other Pancultural Constructs? Journal of Cross-Cultural Psychology, 35(4), 367-402.

Takahashi, K. (1986). Examining the strange-situation procedure with Japanese mothers and 12-month-old infants. Developmental Psychology, 22(2), 265-270. 
Tóth I., \& Gervai J. (2005). A kötôdés minôségének mérése a csecsemő- és óvodáskorban. Alkalmazott Pszichológia, 7(4), 14-26.

Tóth I. (2011). Az érzelmi-társas kapcsolatok fejlődése: korai gondozás és kötôdés. In Danis I., Farkas M., Herczog M., Szilvási L. \& Balázs I. (szerk.), A génektôl a társadalomig: a koragyermekkori fejlốdés szinterei (pp. 320-372). Budapest: Nemzeti Család- és Szociálpolitikai Intézet (NCSSZI).

Trommsdorff, G., \& Friedlmeier, W. (2010). Preschool girls' distress and mothers' sensitivity in Japan and Germany. European Journal of Developmental Psychology, 7, 350-370.

You, H. S., \& Malley-Morrison, K. (2000). Young adult attachment styles and intimate relationships with close friends: A cross-cultural study of Koreans and Caucasian Americans. Journal of Cross-Cultural Psychology, 31, $528-534$.

Van IJzendoorn, M.H., \& Sagi, A. (1999). Cross-cultural patterns of attachment: Universal and contextual dimensions. In J. Cassidy \& P. Shaver (Eds.), Handbook of attachment (pp. 880-906). New York: Guilford Press.

Van IJzendoorn, M. H., Schuengel, C., \& Bakermans-Kranenburg, M. J. (1999). Disorganized attachment in early childhood: Meta-analysis of precursors, concomitants, and sequelae. Development and Psychopathology, 11(02), 225-250.

Van IJzendoorn, M. H., Vereijken, C. M., Bakermans-Kranenburg, M. J., \& Marianne RiksenWalraven, J. (2004). Assessing attachment security with the attachment Q sort: Meta-analytic evidence for the validity of the observer AQS. Child Development, 75(4), 1188-1213.

Van IJzendoorn, M. H., \& Sagi-Schwartz, A. (2008). Cross-cultural patterns of attachment: Universal and contextual dimensions. In J. Cassidy \& P.R. Shaver (Eds.), Handbook of attchment: Theory, Research, and Clinical Applications (pp. 880-905).New York: Guilford Press.

Waters, E., \& Deane, K. E. (1985). Defining and assessing individual differences in attachment relationships: Q-methodology and the organization of behavior in infancy and early childhood. Monographs of the Society for Research in Child Development, 50(1-2), 41-65.

Wang, C. C. D., \& Mallinckrodt, B. S. (2006). Differences between Taiwanese and US cultural beliefs about ideal adult attachment. Journal of Counseling Psychology, 53(2), 192-204.

\title{
CULTURAL DIFFERENCES IN ATTACHMENT
}

\author{
FÜLÖP, MÁRTA - SZABÓ, ZSÓFIA ÉVA
}

This review presents the theory of attachment from the perspective of cultural comparative studies. Attachment is considered a universal phenomenon, however the main developmental criteria described by the classical theory and the different attachment patterns are seen as also culturally determined. The review summarizes cross-cultural research on attachment in the last sixty years. At first it presents those studies that took the etic perspective and conceptualized cultural differences in the differences of quantitative distribution of different attachment patterns. It continues with the emic approaches which question several of the basic postulations of attachment theory for example the monotropization of the mother-child relationship and the universality of the criteria of the mother's sensitivity. The study emphasizes that the function of attachment is the most effective adaptation to the biological and social-cultural environment of the child and if this socio-cultural environment is qualitatively different from the Western, Euro-American then the attachment processes will be different as well.

Keywords: attachment, cultural differences, mother-child relationship 